\title{
New mutations in flagellar motors identified by whole genome sequencing in Chlamydomonas
}

\author{
Huawen Lin, Nicholas P Nauman, Alison J Albee, Silas Hsu and Susan K Dutcher ${ }^{*}$
}

\begin{abstract}
Background: The building of a cilium or flagellum requires molecular motors and associated proteins that allow the relocation of proteins from the cell body to the distal end and the return of proteins to the cell body in a process termed intraflagellar transport (IFT). IFT trains are carried out by kinesin and back to the cell body by dynein.
\end{abstract}

Methods: We used whole genome sequencing to identify the causative mutations for two temperature-sensitive flagellar assembly mutants in Chlamydomonas and validated the changes using reversion analysis. We examined the effect of these mutations on the localization of IFT81, an IFT complex B protein, the cytoplasmic dynein heavy chain (DHC1b), and the dynein light intermediate chain (D1bLIC).

Results: The strains, fla18 and fla24, have mutations in kinesin-2 and cytoplasmic dynein, respectively. The fla18 mutation alters the same glutamic acid $\left(E_{24} G\right)$ mutated in the fla10-14 allele $\left(E_{24} \mathrm{~K}\right)$. The fla18 strain loses flagella at $32^{\circ} \mathrm{C}$ more rapidly than the $E_{24} \mathrm{~K}$ allele but less rapidly than the fla10-1 allele. The fla18 mutant loses its flagella by detachment rather than by shortening. The fla24 mutation falls in cytoplasmic dynein and changes a completely conserved amino acid $\left(\mathrm{L}_{3243} \mathrm{P}\right)$ in an alpha helix in the AAA5 domain. The fla24 mutant loses its flagella by shortening within 6 hours at $32^{\circ} \mathrm{C}$. DHC1b protein is reduced by 18 -fold and D1bLIC is reduced by 16 -fold at $21^{\circ} \mathrm{C}$ compared to wild-type cells. We identified two pseudorevertants $\left(\mathrm{L}_{3243} \mathrm{~S}\right.$ and $\left.\mathrm{L}_{3243} \mathrm{R}\right)$, which remain flagellated at $32^{\circ} \mathrm{C}$. Although fla24 cells assemble full-length flagella at $21^{\circ} \mathrm{C}$, IFT81 protein localization is dramatically altered. Instead of localizing at the basal body and along the flagella, IFT81 is concentrated at the proximal end of the flagella. The pseudorevertants show wild-type IFT81 localization at $21^{\circ} \mathrm{C}$, but proximal end localization of IFT81 at $32^{\circ} \mathrm{C}$.

Conclusions: The change in the AAA5 domain of the cytoplasmic dynein in fla24 may block the recycling of IFT trains after retrograde transport. It is clear that different alleles in the flagellar motors reveal different functions and roles. Multiple alleles will be important for understanding structure-function relationships.

Keywords: Kinesin-2, Cytoplasmic dynein, IFT81, Ciliary assembly, IFT recycling, Whole genome sequencing

\section{Background}

The building of a cilium or flagellum requires molecular motors and associated proteins in a process termed intraflagellar transport (IFT). IFT was first described as a bidirectional movement of 'granule-like' particles along the axoneme in Chlamydomonas reinhardtii [1]. Concurrently, a novel heterotrimeric kinesin was isolated from sea urchin embryos [2]. A temperature-sensitive mutation in the Chlamydomonas FLA10 gene shows it is needed for flagellar assembly [3], and that IFT is dependent upon FLA10

\footnotetext{
* Correspondence: dutcher@genetics.wustl.edu

Department of Genetics, Washington University, 660 South Euclid Avenue, St Louis, MO 63110, USA
}

[4]. FLA10 encodes a subunit of the heterotrimeric kinesin first found in sea urchins $[5,6]$. The Chlamydomonas FLA8 and FLA3 genes encode the other kinesin-2 motor subunit and the kinesin-associated protein (KAP) subunit, respectively $[7,8]$. The IFT trains are composed of at least 19 proteins, which fall into two complexes, $\mathrm{A}$ and $\mathrm{B}$, which are dissociated by salt $[5,6]$. Complex B contributes to anterograde transport away from the cell body [5], and complex $\mathrm{A}$ is involved in retrograde transport toward the cell body [9-11]. Anterograde movement requires kinesin-2 and retrograde movement requires cytoplasmic dynein. At the tip, the anterograde IFT particles rearrange into new trains with a different shape and size for retrograde IFT [12]. This

\section{Biomed Central}

(C) 2013 Lin et al.; licensee BioMed Central Ltd. This is an open access article distributed under the terms of the Creative Commons Attribution License (http://creativecommons.org/licenses/by/2.0), which permits unrestricted use, distribution, and reproduction in any medium, provided the original work is properly cited. 
simple picture is made more complex by examining the behavior of the BBSome in Caenorhabditis elegans [13]. The BBSome is a complex of seven proteins [14] that is postulated to be involved in the import of $\mathrm{G}$ protein coupled receptors in mammalian cells $[15,16]$ and the export of cycling proteins in Chlamydomonas [17]. The BBSome may regulate anterograde IFT assembly and then rearrangement at the tip [13]. Cargo-specific adapter proteins may be important for IFT transport of cargo [18]. IFT is essential for mammalian development as mutants in various IFT proteins are lethal in mice (reviewed in Eggenschwiler and Anderson [19]). Mutations in several IFT proteins and cytoplasmic dynein cause asphyxiating thoracic dystrophy in humans [20-23].

A collection of temperature-sensitive mutants in Chlamydomonas that assemble flagella at the permissive temperature of $21^{\circ} \mathrm{C}$, but lack flagella at the restrictive temperature of $32^{\circ} \mathrm{C}$ (Table 1) provides an important resource for the analysis of flagellar assembly $[11,24,25]$. Since many conditional mutants have reduced but sufficient function at the permissive temperature, this collection offers the opportunity to examine IFT in assembled flagella at the permissive temperature to ask about the effects of reduced function. For example, the temperaturesensitive allele in IFT172 suggests a role in remodeling IFT at the tip [26]. IFT is required to transport many of the flagellar proteins from the cytoplasm to the flagella. These include the inner dynein arm protein p28 that fails to be imported in the fla10-1 mutant [6]. Recent isobaric tags for relative and absolute quantitation (iTRAQ) experiments suggest that numerous proteins accumulate or are depleted in the presence of a mutant cytoplasmic dynein even when the length of the flagella has not changed [27], which shows the importance of retrograde movement for moving proteins back to the cell body.

The role of IFT differs between different axonemal proteins/cargos. Piperno et al [6] used temporary dikaryons, which are formed by the mating of two parental cells, to examine the kinetics and localization of proteins using antibodies to proteins in axonemal structures. The parental strains both carried the temperature-sensitive fla10-1 mutation in kinesin-2 [3] that stops IFT within 30 minutes after the shift to the restrictive temperature. One parent is otherwise wild-type, while the other parent has either an oda6 mutation that blocks assembly of the outer dynein arms [45] or an ida4 mutation that blocks assembly of a subset of inner dynein arms [46]. In ida4 $\mathrm{x}$ wild-type dikaryons at $21^{\circ} \mathrm{C}$, IDA4 appear at the distal end of the mutant flagella by antibody staining and staining moved towards the proximal end with time after mating. In oda6 $\mathrm{x}$ wild-type dikaryons, ODA6 behave very differently. Staining appears along the entire length of the flagella 6 minutes after mating. The intensity increased with time. To test the role of IFT in the incorporation of dynein arm proteins, the parental cells were shifted to $32^{\circ} \mathrm{C}$ for 30 minutes to inactivate kinesin-2. The incorporation of IDA4 was blocked at the restrictive temperature, while ODA6 continued to be incorporated. Thus, the outer dynein arms appear to enter by diffusion or by a different motor complex [6], while the entry of the inner arm component requires kinesin-2. Transport of outer dynein arms also requires an adapter between the dynein arms and IFT. ODA16 functions as a cargo-specific adaptor between IFT particles and outer row dynein needed for efficient dynein transport into the flagellar compartment, as shown by its localization and interactions by immunoprecipitation and yeast two-hybrid experiments [18]. Recent results suggest that transport of tubulin into cilia is mediated by a weak affinity between tubulin and IFT81 and IFT74 [47].

Analysis of IFT using differential interference contrast (DIC) optics and kymographs showed that six of these conditional mutants have defects in the number of anterograde IFT particles or their velocity at $21^{\circ} \mathrm{C}$, six have defects in either retrograde IFT particle number or velocity at $21^{\circ} \mathrm{C}$, and four have no change in IFT particle number or velocity at $21^{\circ} \mathrm{C}$ (Table 1 ). As genes have been identified, it is clear that alleles in the same gene have slightly different properties; these differences must reflect the properties of the mutant alleles and not the function of the gene. For example, the fla 1 and fla $8 \mathrm{mu}-$ tants both encode the other motor subunit of kinesin-2 [8] but show differences in the behavior of IFT particles [11]. These differences may reflect the degree of activity/ concentration of the mutant proteins at the permissive temperature.

In Chlamydomonas, seven genes needed for intraflagellar transport have been identified by conditional alleles (Table 1). Nonconditional mutations in nine additional genes as well as in three of the genes with conditional alleles have been identified. RNA depletion of two IFT genes has been analyzed in Chlamydomonas and result in short flagella (Table 1), which may occur because there is only partial knockdown of the genes. Eighteen of the IFT and motor protein genes have mutants or depletion results. In this report, we employed whole genome sequencing to identify the FLA18 and FLA24 genes. These genes encode a new allele in the FLA10 kinesin-2 motor subunit and a new allele in the cytoplasmic dynein DHC1b, respectively.

\section{Methods}

\section{Strains and culture conditions}

Strains were obtained from the Chlamydomonas Resource Center (University of Minnesota, St Paul, MN, USA): fla18, CC-3864; fla24, CC-3866; 137M, CC-124; 137P, CC-125; S1C5, CC-1952; and S1D2, CC-2290. Each fla strain was backcrossed three times to either $137 \mathrm{P}$ or $137 \mathrm{M}$ strains to remove any unlinked modifiers. 
Table 1 Phenotypes of intraflagellar transport (IFT) mutants and depletion

\begin{tabular}{|c|c|c|c|c|}
\hline \multicolumn{5}{|c|}{ Conditional IFT mutants in Chlamydomonas } \\
\hline Gene & IFT phenotype at $21^{\circ} \mathrm{C}$ & Protein & Other names & Reference(s) \\
\hline FLA1 & Reduced anterograde velocity and train number & Kinesin-2 motor subunit & flas-2 & {$[8,11,24,25]$} \\
\hline FLA2 & Reduced retrograde velocity and train number & Unknown & & {$[24,25,28]$} \\
\hline FLA3 & Reduced frequency of anterograde trains & KAP subunit of kinesin-2 & & {$[7,11,24,25]$} \\
\hline FLA4 & Wild-type & Unknown & & {$[24,25]$} \\
\hline FLA5 & Wild-type & Unknown & & {$[11,24,25]$} \\
\hline FLA6 & Not tested & No longer extant & & {$[24,25]$} \\
\hline FLA7 & Not tested & Kinesin-2 motor subunit & fla10-14 & {$[8,24,25,29]$} \\
\hline FLA8 & Anterograde & Kinesin-2 motor subunit & fla8-1 & {$[8,25,30]$} \\
\hline FLA9 & Wild-type & IFT81 & & [25], (unpublished data) \\
\hline FLA10 & Reduced anterograde velocity and train number & Kinesin-2 motor subunit & fla10-1 & {$[3,25,30]$} \\
\hline FLA11 & Reduced retrograde velocity and train number & IFT172 & fla11-1 & {$[11,25,26]$} \\
\hline FLA12 & Faster anterograde and retrograde velocities & Unknown & & {$[11,29]$} \\
\hline FLA13 & Not tested & Unknown & & {$[11,29]$} \\
\hline FLA15 & Reduced retrograde velocity and train number & IFT139 & & {$[11,31]$} \\
\hline FLA16 & Reduced retrograde velocity and train number & IFT144 & fla17-2 & {$[11,31]$} \\
\hline FLA17 & Reduced retrograde velocity and train number & IFT144 & & {$[11,31]$} \\
\hline FLA18 & Reduced anterograde velocity and train number & Kinesin-2 motor & fla10-16 & {$[11]$, this report } \\
\hline FLA21 & Wild-type & Unknown & & [11] \\
\hline FLA24 & Reduced retrograde velocity and train number & $\mathrm{DHC1b}$ & & {$[11]$, this report } \\
\hline FLA27 & Decreased anterograde train number with wild-type velocity & Unknown & & [11] \\
\hline FLA28 & Reduced anterograde velocity and train number & Unknown & & [11] \\
\hline $\mathrm{DHClb}$ & Reduced retrograde velocity and train number & Cytoplasmic dynein & $d h c 1 b^{t s} ; d h c b 1-3$ & {$[11,27,32]$} \\
\hline
\end{tabular}

Nonconditional IFT mutants in Chlamydomonas

\begin{tabular}{lllll}
\hline Gene & Phenotype & Protein & & \\
\hline FLA8 & Aflagellate & Kinesin-2 motor subunit & fla8-3 & {$[30]$} \\
FLA10 & Aflagellate & Kinesin-2 motor subunit & fla10-2 & {$[33]$} \\
FLA14 & Short flagella & LC8 & {$[34]$} \\
IFT46 & Short, paralyzed flagella & IFT46 & {$[18,35,36]$} \\
BLD1 & Aflagellate & IFT52 & {$[37,38]$} \\
IFT80 & Aflagellate & IFT80 & {$[30]$} \\
IFT88 & Very short flagella & IFT88 & {$[36,39,40]$} \\
IFT121 & Aflagellate & IFT121 & {$[41]$} \\
IFT122 & Aflagellate & IFT122 & dhcb1; spt1-1; spt1-2 \\
DHC1b/SPT1 & Very short flagella & [9,10] \\
D16LIC & Variable flagellar length & DHC1b & D1blic-1 & {$[42]$} \\
RNAi depletion IFT strains in Chlamydomonas & D1bLIC & {$[44]$} \\
IFT27 & Short flagella & & {$[43]$} \\
IFT70 & Short flagella & Rab-like & IFT70/Dyf1
\end{tabular}

IFT, intraflagellar transport; KAP, kinesin-associated protein.

Whole genome sequencing

Chlamydomonas genomic DNA preparation for whole genome sequencing was prepared as described previously [30]. Three micrograms of DNA were submitted to Genome Technology Access Core (St Louis, MO, USA) for library construction, Illumina sequencing (San Diego, CA, USA), and initial data analysis. For multiplex Illumina sequencing, 7-nucleotide indexes were added to 
individual DNAs during the library construction before the samples were subjected to sequencing. The fla18 and fla24 samples were tagged with TGAGGTT and GCTTAGA, respectively, and shared the same sequencing lane with two other samples. All resulting sequencing data were de-multiplexed before being subjected to sequence alignment and SNP calling.

\section{dCAPS markers and segregation analysis}

Restriction enzymes that provide differences between mutant and wild-type alleles are listed in Additional file 1: Table S1. For fla24, NEBCutter (New England BioLabs, Ipswich, MA, USA) was used to find the appropriate restriction enzyme. However, no restriction enzyme distinguishes between CC-125 and fla18. A dCAPS marker was designed using dCAPS Finder 2.0 (Washington University, St Louis, MO, USA) [48]. A forward primer (fla18-dcapF) introduces a mismatch immediately upstream of the point mutation that creates an MboII recognition site in the wild-type PCR product $\left(\right.$ GAAGA $\left.(\mathrm{N})_{8}\right)$ but not in the fla18 PCR product $\left(\mathrm{GAGGA}(\overline{\mathrm{N}})_{8}\right)$. The $132 \mathrm{bp}$ PCR product, when digested with MboII, generates $102 \mathrm{bp}$ and $30 \mathrm{bp}$ fragments from wild-type but is uncut in fla18.

\section{Flagellar isolation}

Flagella were isolated as described previously $[49,50]$ with the addition of Protease Arrest (G-Biosciences, St Louis, MO, USA).

\section{Flagellar counts}

Cells were grown overnight in a $21^{\circ} \mathrm{C}$ lighted incubator to a density of approximately $2 \times 10^{6}$ cells $/ \mathrm{ml}$. Cells were then transferred to a $32^{\circ} \mathrm{C}$ lighted incubator and samples were taken every hour. Samples were prepared by spotting $19 \mu \mathrm{L}$ of cells onto a microscope slide and adding $1 \mu \mathrm{L}$ of $2 \%$ glutaraldehyde in $0.1 \mathrm{M}$ phosphate buffer (pH 7.0) directly to the spotted cells. A total of 200 cells from each strain at each time point were scored using phase optics (40x) for the presence or absence of flagella. Flagellar length was monitored by immunofluorescence with monoclonal antibody to acetylated $\alpha$-tubulin (SigmaAldrich, St Louis, MO, USA) at a dilution of 1:1,000.

\section{Immunoblots and immunofluorescence}

The antibodies were: ift81.3 (a gift from Dr Doug Cole) for immunofluorescence at 1:200; $\alpha$-tubulin (DM1 $\alpha$ from Sigma-Aldrich) used for immunoblots at 1:5,000, DHC1b and D1bLIC (a gift from Dr George Witman, University of Massachusetts, Worcester, MA, USA) were used for immunoblots at 1:2,000 and for immunofluorescence at 1:100; and $\varepsilon$-tubulin was used at 1:500 for immunofluorescence [51]. For immunoblots, flagellar proteins were isolated and resuspended in HEPES/Sr/DTT/sucrose buffer [52]. All the protein samples were stored at $-80^{\circ} \mathrm{C}$ before use. Protein concentrations were ascertained by using BioRad protein assay (Bio-Rad, Hercules, CA, USA) following the manufacturer's instruction. The proteins were boiled for 5 minutes and centrifuged for 1 minute before loading onto the gel. The proteins were size-fractionated on SDS-PAGE minigels $(1.0 \mathrm{~mm}$ thick, $6 \%$ acrylamide gel (for DHC1b) or 10\% acrylamide gel (for D1bLIC) prepared from $30 \%$ acrylamide and bis-acrylamide solution, 29:1 (BioRad, Hercules, CA, USA)) and transferred to Immobilon-P PVDF membranes (EMD Millipore, Billerica, MA, USA) in $25 \mathrm{mM}$ Tris, $192 \mathrm{mM}$ glycine buffer containing $20 \%$ methanol at $62 \mathrm{v}$ for one hour. The incubation with primary antibody was incubated overnight at $4^{\circ} \mathrm{C}$. The blots were washed three times for 10 minutes each in PBST. The secondary antibody was incubated at room temperature for 1 hour. Goat anti-mouse HRP (BioRad) and goat anti-rabbit HRP (Sigma-Aldrich) were used at 1:5,000 dilution. SuperSignal West Femto Chemiluminescent Substrate (Thermo Scientific, Waltham, MA, USA) was used according to the manufacturer's instructions. The blots were imaged on a FluorChem H2 imager (Alpha Innotech, Santa Clara, CA, USA). Signal quantification analysis was performed by ImageJ (National Institutes of Health (NIH), Bethesda, MD, USA).

For immunofluorescence, Alexa 488 goat anti-rabbit (Invitrogen, Grand Island, NY, USA) and Alexa 594 goat anti-mouse were used at a 1:500 dilution with published protocols [51], except newborn goat serum and fish gelatin were not used. All individual immunofluorescence channels were maintained with the same exposure time throughout the time courses.

\section{Results}

To identify and understand the function of genes that can be mutated to a temperature-sensitive flagellar assembly phenotype, we are using whole genome sequencing. Mutants with an anterograde IFT defect (fla18) and a retrograde IFT defect (fla24) were chosen for analysis [11]. Each mutant was crossed to wild-type (CC124 or CC-125) to verify that the phenotype segregated as a single mutation in meiotic progeny. In 56 and 130 tetrads, respectively, the aflagellate phenotype at $32^{\circ} \mathrm{C}$ segregated two wild-type and two mutant progeny, which suggests a single mutation or several tightly linked mutations. Each mutant was subjected to whole genome sequencing. The coverage ranged from 51-fold for fla24 to 94-fold for fla18 (Table 2).

\section{FLA18 encodes a kinesin-2 subunit}

The fla18 mutant strain was crossed to the highly polymorphic strain S1C5 and one fla18 meiotic progeny was subjected to whole genome sequencing [8]. About $71 \%$ of the $101 \mathrm{bp}$ reads align to the reference genome (Table 2). A total of 43,103 SNPs/indels unique to the fla18 mutant 
Table 2 Changes in fla18 and fla24 strains by whole genome sequencing

\begin{tabular}{lllllll}
\hline Mutant strain & $\begin{array}{l}\text { Sequencing reads } \\
\text { (101 bp, paired-ended) }\end{array}$ & $\begin{array}{l}\text { Aligned reads \% } \\
\text { (coverage) }\end{array}$ & $\begin{array}{l}\text { Number of changes } \\
\text { across the genome }\end{array}$ & Chromosome & Position & Change \\
\hline fla18 & 157313244 & $70.7 \%(94 \mathrm{x})$ & 892 & 17 & 4328331 & $\mathrm{gAg} / \mathrm{gGg} \mathrm{E} \mathrm{to} \mathrm{G}$ \\
fla24 & 63540680 & $95.3 \%(51 \mathrm{x})$ & 62 & 6 & 165063 & $\mathrm{cTg} / \mathrm{cCg} \mathrm{L} \mathrm{to} \mathrm{P}$ \\
\hline
\end{tabular}

strain were found after subtracting the SNPs/indels found in 15 other Chlamydomonas strains [53]. Among this set of SNPs/indels, 892 changes map to exons or intron/exon boundaries when synonymous changes are excluded (Table 2).

In our study of transcript levels following $\mathrm{pH}$ shock at various time points during flagellar assembly [54], we found that all of the IFT genes are upregulated at least 2.5-fold within 1 hour of flagellar amputation. Given the fla18 mutant strain has a defect in anterograde IFT [11], we hypothesized that the FLA18 gene is likely to be among the 1,850 upregulated genes. A comparison between the list of genes that have SNPs/indels in fla18 and the list of upregulated genes identifies 85 SNPs/ indels in 59 genes. One of the changes is a glutamic acid (GAG) to glycine (GGG) in the FLA10 kinesin $\left(\mathrm{E}_{24} \mathrm{G}\right.$, Table 3). In the fla10-14 mutant strain, the same glutamic acid is replaced by lysine $\left(\mathrm{E}_{24} \mathrm{~K}\right)$ [8]. We then verified that the temperature-sensitive phenotype was linked to FLA10 in 20 progeny from a cross of fla18 x S1C5 (Table 3). The FLA10 gene is located at $4.43 \mathrm{Mb}$ on chromosome 17. The fla18 maps 5 map units $(\mathrm{mu})$ from a marker at 4.0 Mb, and markers at $2.23 \mathrm{Mb}$ and $6.8 \mathrm{Mb}$ show weaker linkage (20 and $16 \mathrm{mu}$, respectively, Table 3 ). These values conform to other crosses where approximately $100 \mathrm{~kb}$ corresponds to $1 \mathrm{mu}$ and indicate that fla18 is linked to the FLA10 gene.

To confirm that this mutation is the causative change in fla18, we isolated revertants of fla18 that regained the ability to swim at $32^{\circ} \mathrm{C}$. Following UV mutagenesis, 46 independent swimming strains were isolated. A dCAPS marker that distinguishes the polymorphism in wild-type and fla 18 was used to analyze 8 of the 46 revertants/suppressors. The restriction enzyme $M b o$ II cuts the wild-type PCR product, but not the fla18 PCR product. A representative gel of the PCR and digest is shown in Figure 1. Digestion by $M b o I I$ indicates that these eight strains are likely to be true revertants. The restoration of the original codon was confirmed in these eight revertants by Sanger sequencing (Table 4). Thus, our revertant analysis indicates that mutation in the FLA10 kinesin is the causative mutation in fla18. To examine the temperature-sensitive phenotype of the fla18 mutant strain, it was shifted from the permissive temperature of $21^{\circ} \mathrm{C}$ to the restrictive temperature of $32^{\circ} \mathrm{C}$, and the percentage of flagellated cells was determined. While wild-type cells remain approximately $80 \%$ flagellated, the fla 18 cells lose their flagella gradually and at 7 hours most cells are aflagellate (Figure 2A). The length of the flagella was measured and the length changed by only $2 \mu \mathrm{m}$ (Figure $2 \mathrm{~B}$ ). The cells may be losing their flagella by detachment rather than by shortening.

\section{FLA24 encodes the cytoplasmic dynein heavy chain}

The fla24 allele was mapped to chromosome 6 near the mating-type locus [31] and linkage to the mating-type locus was confirmed in an additional 243 tetrads (239:0:4; PD:NPD:T). There is only one change in fla 24 in the mapped interval after subtracting changes found in other unrelated strains [53]. The candidate in the interval is $\mathrm{DHC1b}$, the cytoplasmic dynein gene for retrograde IFT (Table 2). The $\mathrm{T}$ to $\mathrm{C}$ mutation predicts a $\mathrm{L}_{3242} \mathrm{P}$ change. We used a PCR-based assay to examine linkage of the flagellar phenotype with the alteration in the cytoplasmic dynein gene. The PCR product generated is $303 \mathrm{bp}$ long in both the fla 24 and wild-type strains. The mutant product is cut by $N c i$ I but not cut by $A l w \mathrm{~N} 1$, while the wild-type product is cut by $A l w \mathrm{~N} 1$ but not by NciI. This change cosegregates with the flagellar assembly defect in 59 meiotic progeny. To ask if this change is responsible for the phenotype, we again used reversion/suppressor analysis. Following mutagenesis, 64 independent swimming strains were recovered. Nine of the strains are no longer cut by NciI. Of these, AlwN1 fails to cut three (Figure 3, Table 5).

Table 3 Primers for mapping of fla18 in crosses with CC-1952 (S1C5)

\begin{tabular}{|c|c|c|c|c|}
\hline Primer name & Sequence $F\left(5^{\prime}\right.$ to $\left.3^{\prime}\right)$ & Sequence $\mathrm{R}\left(5^{\prime}\right.$ to $\left.3^{\prime}\right)$ & $\begin{array}{l}\text { Product size in fla18 and } \\
\text { restriction enzyme }\end{array}$ & $\begin{array}{l}\text { Fla18:S1C5 parental to } \\
\text { recombinant progeny }\end{array}$ \\
\hline Ch17-0.5 & GCA CAG CTG AAG CGC AAA AGG AAG C & CGT TTC TCG AAC TCA GCC ACT GT & Hindlll $180 \mathrm{bp}$ & 11:9 Unlinked \\
\hline LC5-2.32 & GGA CGG TGG GTA TGC ATT AG & GCT GTC ACT ACG TGG TCT CG & Mspl 203 bp & 15:5 (20 mu) \\
\hline Ch17-4.03 & ATA TTA CGC CTC TCC GAC AAC AGC & CAG CTT CTT TGT GCG CTT GTA CTT & $-271 \mathrm{bp}$ & $19: 1$ (5 mu) \\
\hline Ch17-6.28 & CAT CGA GCT GCT TGG AGG CCA GAT A & CGC TAT ACA CCA CAT AGC GTC GAG & $-147 \mathrm{bp}$ & $16: 4$ (16 mu) \\
\hline
\end{tabular}

Markers without a restriction enzyme generate size polymorphisms due to CA repeats. All reactions were performed with an annealing temperature of $53^{\circ} \mathrm{C}$. 


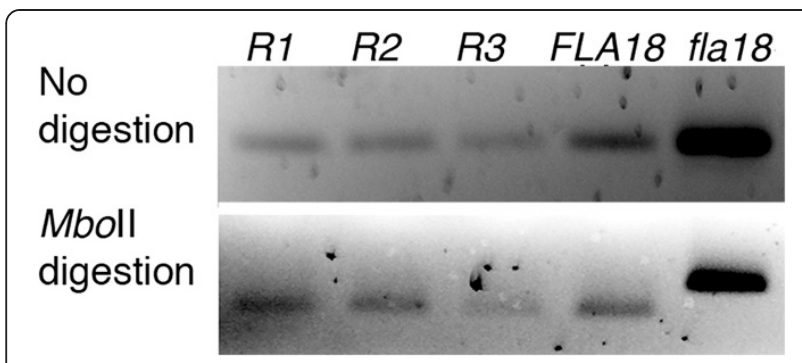

Figure 1 PCR assays to provide evidence for identifying the fla18 gene by reversion. A dCAPS marker shows reversion of fla18. Upper panel, a 132 bp PCR fragment was amplified in wild-type, fla18, and three fla18 true revertants $(R 1, R 2$, and $R 3)$. Lower panel: the amplified fragment was subjected to Mboll digestion, which generates a $103 \mathrm{bp}$ fragment if the enzyme site is present in the PCR product.

Sanger sequencing verified that we recovered six true revertants that changed the proline at amino acid 3243 back to leucine, and three pseudorevertants that changed the proline to either serine (2) or to arginine (1).

Currently, there are five other mutant alleles identified in the cytoplasmic dynein gene in Chlamydomonas. Three show nonconditional phenotypes; they assemble very short flagella $[9,10]$, and two temperature-sensitive alleles have been identified. The $d h c 1 b^{t s}$ allele assembles one-half length flagella $(5.5$ to $6 \mu \mathrm{m})$ at the permissive temperature of $18^{\circ} \mathrm{C}$. Upon shifting cells to the restrictive temperature, the flagella shorten by about one-half in 2.5 hours and are very short by 24 hours [32]. The $d h c 1 b-3$ allele shows a very slow decrease in flagellar length and number upon shifting from $21^{\circ} \mathrm{C}$ to $34^{\circ} \mathrm{C}$ [27]. It takes nearly 4 days for the cells to shorten their flagella. We determined the number of cells with flagella in the fla24 allele (Figure 2C). In contrast to the other conditional alleles, the fla24 allele shows much faster shortening and loss of flagella. By 2.5 hours, there is noticeable shortening, and by 6 hours the population is aflagellate (Figure 2D). The true revertant and two pseudorevertants ( $\mathrm{P}$ to $\mathrm{S}$ and $\mathrm{P}$ to $\mathrm{R}$ ) remain flagellated at the restrictive temperature over the same time period as would be expected (Figure 2C).

\section{DHC1b and D1bLC are reduced in fla24 at the restrictive temperature}

DHC1b localizes to the basal body region and along the flagella in both wild-type and fla 24 at $21^{\circ} \mathrm{C}$. At this temperature, the signal intensities at the basal body and in the flagella are comparable between wild-type and fla24 cells (Figure 4A). In the $d h c 1 b-3$ allele, the levels of DHC1b and the dynein light intermediate chain D1bLIC are reduced when cells were shifted to $34^{\circ} \mathrm{C}$ [27]. After the shift to $32^{\circ} \mathrm{C}$, the wild-type cells maintain the same localization and similar signal intensity of DHC1b throughout the assay (5 hours). However, the intensity of DHC1b at the basal body and flagella in fla24 cells starts to show a reduction within 2 hours, before the majority of cells lost their flagella (Figures 2 and 4). The DHC1b signal remains detectable in the basal body area, but decreases with time at the restrictive temperature. By immunoblots, we showed that DHC1b is reduced by 18 -fold in fla24 flagella compared to wildtype flagella (Figure $4 \mathrm{C}$ ). In contrast, the three revertants (D11, D12, and D42b) show similar signal intensities and locations to wild-type cells at both the permissive and restrictive temperatures (Figure $4 \mathrm{~B}$ and Additional file 2: Figure S1).

The localization of D1bLIC in wild-type cells appears similar to that of DHC1b. The signal intensities of D1bLIC remain high in wild-type cells at $21^{\circ} \mathrm{C}$ and for at least 5 hours after cells are shifted to $32^{\circ} \mathrm{C}$ (Figure $5 \mathrm{~A}$ ). However, in fla24 cells, even though D1bLIC shows similar localization, the signal intensity is greatly reduced when compared to wild-type cells at $21^{\circ} \mathrm{C}$ (Figure 5A). The signal shows further reduction as cells lose their flagella (Figure $5 \mathrm{~A}, 32^{\circ} \mathrm{C}, 2$ to 5 hours). The level of D1bLIC

Table 4 Reversion of fla 18 allele provides evidence of causality

\begin{tabular}{|c|c|c|c|c|}
\hline Strain name & Mboll & Sequence for digestion (underline) ${ }^{a}$ & Amino acid & Sanger sequence \\
\hline Wild-type & Cut & GAAGAAGGCAGAT & Glutamic acid & GAG \\
\hline fla18 & Not cut & GAGGAAGGCAGAT & Glycine & GGG \\
\hline R1 & Cut & GAAGAAGGCAGAT & G to $E$ & $\mathrm{G} \mathbf{G G}$ to $\mathrm{GAG}$ \\
\hline R2 & Cut & GAAGAAGGCAGAT & G to $E$ & GGG to $\mathrm{GAG}$ \\
\hline R3 & Cut & GAAGAAGGCAGAT & G to $E$ & $\mathrm{G} \mathbf{G G}$ to $\mathrm{GAG}$ \\
\hline R5 & Cut & $\underline{\text { GAAGAAGGCAGAT }}$ & $G$ to $E$ & GGG to $G \mathbf{A G}$ \\
\hline R6 & Cut & GAAGAAGGCAGAT & G to $E$ & GGG to $\mathrm{GAG}$ \\
\hline R7 & Cut & GAAGAAGGCAGAT & $G$ to $E$ & GGG to $\mathrm{GAG}$ \\
\hline$R 8$ & Cut & GAAGAAGGCAGAT & G to $E$ & $\mathrm{G} \mathbf{G G}$ to $\mathrm{GAG}$ \\
\hline$R 9$ & Cut & GAAGAAGGCAGAT & $G$ to $E$ & $\mathrm{G} \mathbf{G G}$ to $\mathrm{G} \mathbf{A} G$ \\
\hline
\end{tabular}

anderlined nucleotides in the third column indicate the recognition site. This site is created by the primers in the wild-type (FLA18) sequence but not in the mutant (fla18) sequence. 


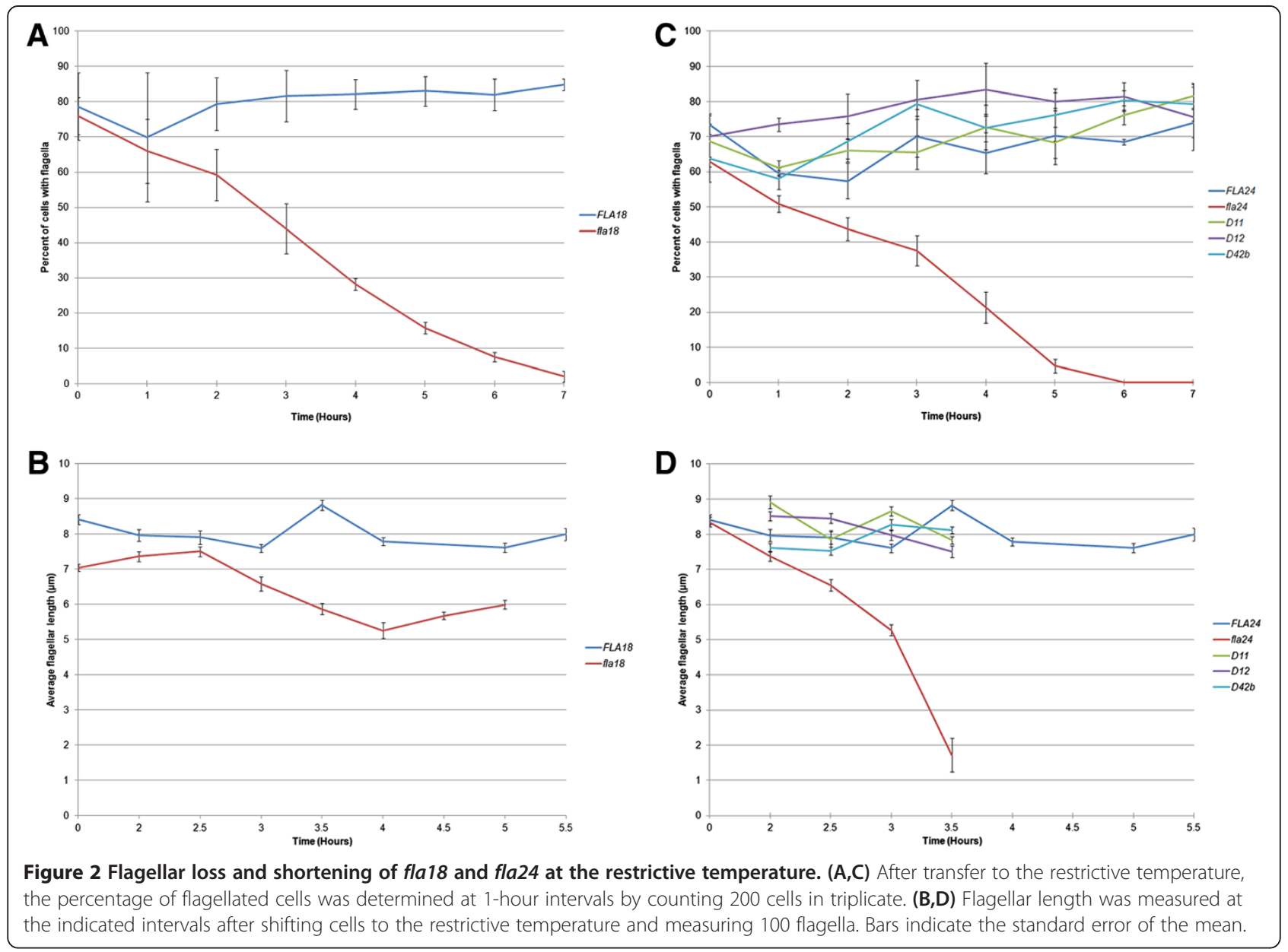

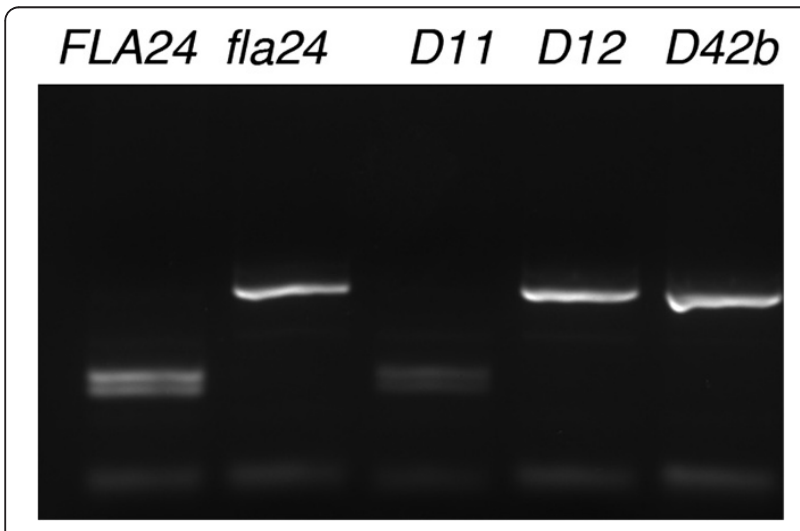

Figure 3 PCR assays to provide evidence for identifying the fla24 gene by reversion. A dCAPS marker shows reversion of fla24. A 303 bp PCR fragment was amplified in wild-type (FLA24), fla24, and three fla24 revertants (D11, D12, and D42b). The amplified fragment was subjected to $A / w N I$ digestion, which generates three fragments of 51,120, and 133 bps if the enzyme site is present in the PCR product as in wild-type and the true revertant (D11), or two fragments of 51 and 273 bps in the fla 24 mutant and pseudorevertants (D12 and D42b). is reduced, as shown by immunoblots of flagellar proteins at $21^{\circ} \mathrm{C}$ by 16 -fold (Figure 4C). An immunoblot of D1bLIC using whole cell extract from wild-type and fla24 cells at $21^{\circ} \mathrm{C}$ indicates that similar to flagellar D1bLIC, the amount of D1bLIC in whole cell extract is reduced approximately 16 -fold in the mutant (Figure $5 \mathrm{C}$ ). We also observed approximately 3 -fold reduction when wildtype cells were switched from $21^{\circ} \mathrm{C}$ to $32^{\circ} \mathrm{C}$ for 5 hours (Figure $5 \mathrm{C}$ ). Consistent with the observation by immunofluorescence (Figure 5A), we were unable to detect the D1bLIC signal by immunoblot after fla24 cells were shifted to $32^{\circ} \mathrm{C}$ for 5 hours (Figure $5 \mathrm{C}$ ). Similar to observation of DHC1b, the signal intensities of D1bLIC remain high in all three revertants (Figure 5B and Additional file 3: Figure S2).

\section{Localization of IFT81 is perturbed at permissive temperature in fla24 but not in fla18}

At the permissive temperature of $21^{\circ} \mathrm{C}$, Iomini et al. found that fla18 IFT trains show a reduced anterograde velocity, and the fla24 IFT particles show a reduced retrograde velocity [11]. These mutant strains have 
Table 5 Reversion of fla24 allele provides evidence of causality

\begin{tabular}{|c|c|c|c|c|c|}
\hline Strain name & AlwNI & Ncil & Sequence for digestion (underline) ${ }^{a}$ & Amino acid & Sequence \\
\hline fla24 & Not cut & Cut & CAGCTGCCGGG & Proline & $\mathrm{CCG}$ \\
\hline Wild-type & Cut & Not cut & $\underline{\text { CAGCTGCTGGG }}$ & Leucine & $\mathrm{CTG}$ \\
\hline D7 & Cut & Not Cut & CAGCTGCTGGG & $P$ to $L$ & $C \mathbf{C G}$ to $\mathrm{CT} G$ \\
\hline D9b & Cut & Not Cut & CAGCTGCTGGG & $P$ to $L$ & $C \mathbf{C G}$ to $\mathrm{CT} G$ \\
\hline D11 & Cut & Not Cut & $\underline{\text { CAGCTGCTGGG }}$ & $P$ to $L$ & $C \mathbf{C G}$ to $C \mathbf{T} G$ \\
\hline D12 & Not cut & Not Cut & CAGCTGTCGGG & $P$ to $S$ & $C \mathrm{CG}$ to $\mathbf{T C G}$ \\
\hline D25b & Cut & Not Cut & CAGCTGCTGGG & $P$ to $L$ & $C \mathbf{C G}$ to $\mathrm{CTG}$ \\
\hline D37 & Cut & Not Cut & CAGCTGCTGGG & $P$ to $L$ & $C \mathbf{C G}$ to $\mathrm{CTG}$ \\
\hline$D 42 b$ & Not cut & Not Cut & CAGCTGCGGGG & $P$ to $R$ & $C \mathbf{C G}$ to $\mathrm{CGG}$ \\
\hline D43 & Not cut & Not Cut & CAGCTGTCGGG & $P$ to $S$ & $C \mathbf{C G}$ to $\mathbf{T C G}$ \\
\hline D57 & Cut & Not Cut & CAGCTGCTGGG & $P$ to $L$ & $C \mathbf{C G}$ to $C \mathbf{T} G$ \\
\hline
\end{tabular}

${ }^{\mathrm{a}}$ The underlined nucleotides in the fourth column indicate the recognition site for Ncil or AlwNI.
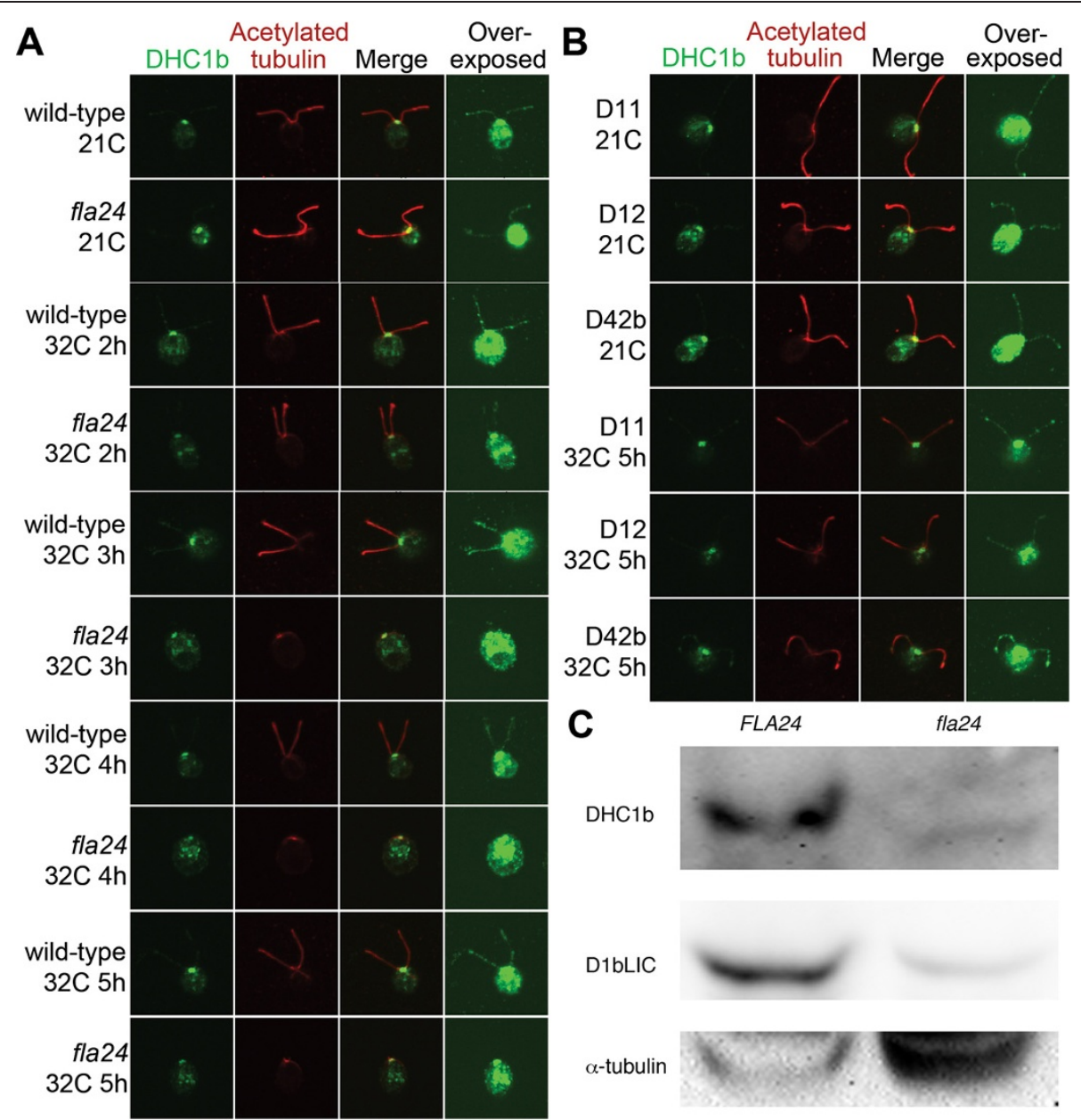

Figure 4 Localization of DHC1b in wild-type, fla24, and fla24 revertants at $21^{\circ} \mathrm{C}$ and $32^{\circ} \mathrm{C}$. DHC1b staining is shown in green (first column) and the flagella are labeled with acetylated a-tubulin (red, second column). Merged images of both staining are shown in the third column. Overexposed DHC1b signals are shown in the forth column to show the localization of DHC1b in the flagella. Cells were obtained from $21^{\circ} \mathrm{C}$ and various time points at $32^{\circ} \mathrm{C}$, as indicated. (A) Wild-type and fla24 cells. (B) fla24 revertants. (C) Twenty micrograms of flagellar proteins were isolated from wild-type (FLA24) and fla24 cells at $21^{\circ} \mathrm{C}$, and probed with DHC1b and D1bLIC antibodies. The membrane that used to probe D1bLIC was stripped and reprobed with a-tubulin to normalize the loading. 


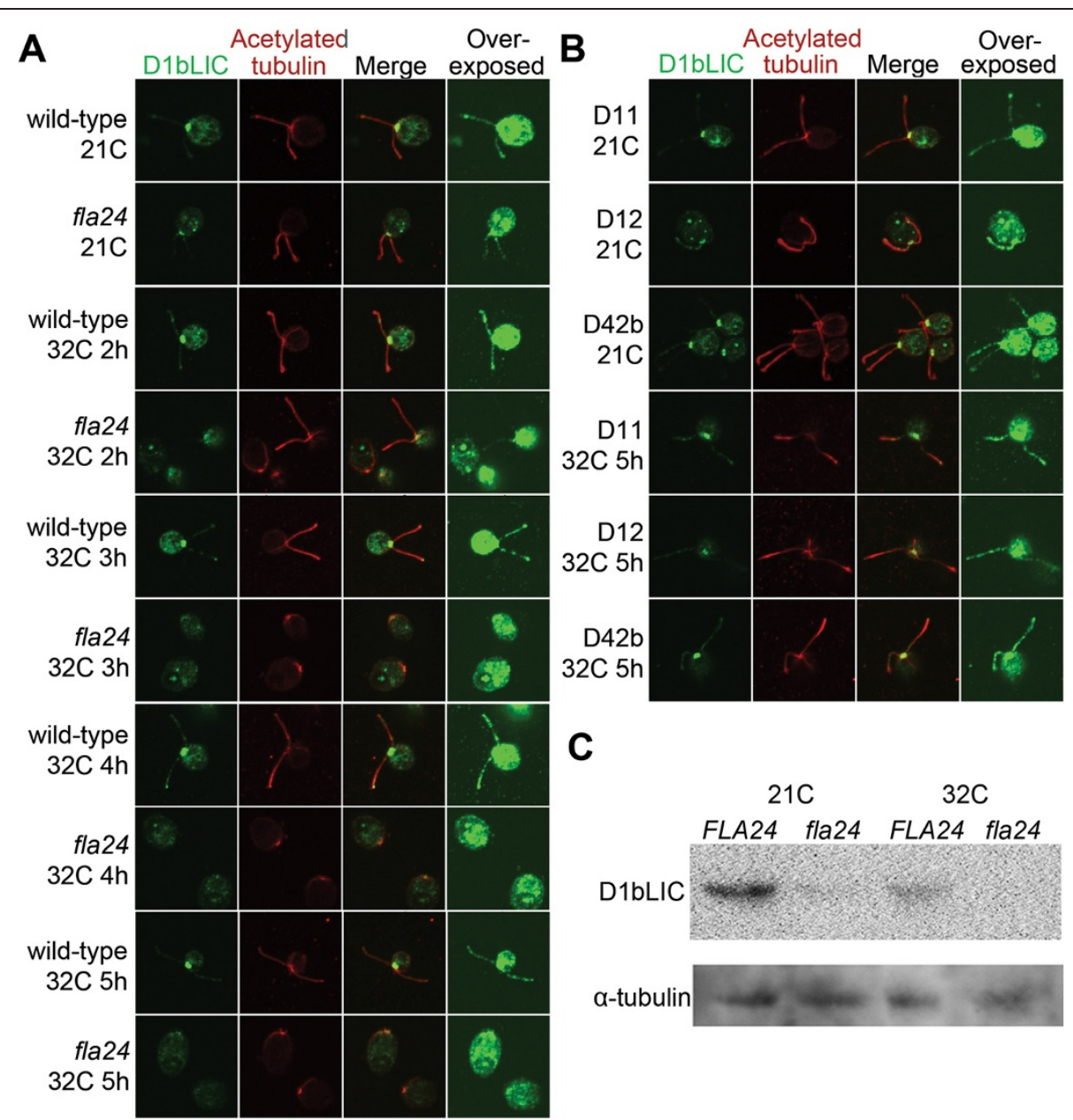

Figure 5 Localization of D1bLIC in wild-type, fla24, and fla24 revertants at $21^{\circ} \mathrm{C}$ and $32^{\circ} \mathrm{C}$. D1bLIC staining is shown in green (first column) and the flagella are labeled with acetylated a-tubulin (red, second column). Merged images of both staining are shown in the third column. Overexposed D1bLIC signals are shown in the forth column to show the localization of D1bLIC in the flagella. Cells were obtained from $21^{\circ} \mathrm{C}$ and various time points at $32^{\circ} \mathrm{C}$, as indicated. (A) Wild-type and fla24 cells. (B) fla24 revertants. (C) Twenty micrograms of whole cell protein extract were isolated from wild-type (FLA24) and fla24 cells at both $21^{\circ} \mathrm{C}$ and $32^{\circ} \mathrm{C}$, and probed with the D1bLIC antibody. The membrane was then stripped and reprobed with a-tubulin to normalize the loading.

defects in the anterograde and retrograde motors, respectively. Therefore, we asked the whether the localization of IFT81, a complex B protein, is affected in these strains.

In the fla 18 mutant strain at the permissive temperature, no change of localization or reduction of intensity of IFT81 was observed when compared to wild-type cells (Figure 6). After cells were shifted to the restrictive temperature, the IFT81 signals remained in the basal body region and in the flagella until the cells became aflagellate at 6 hours. IFT81 appears unperturbed by the fla 18 mutation.

In the fla 24 mutant strain at the permissive temperature, the majority of the IFT81 protein is not localized at the basal body as observed in wild-type and the other mutants, but accumulates in the proximal ends $(0.4$ to $1.4 \mu \mathrm{m} ; \mathrm{n}=$ 20) of flagella regardless of their flagellar length (Figure 7A). This accumulation remains unchanged after cells were shifted to restrictive temperature $\left(32^{\circ} \mathrm{C}\right)$ until flagella are lost. In the true revertant (D11) of fla24, IFT81 localizes to the basal body region and flagella at both temperatures, as observed in wild-type cells (Figure $7 \mathrm{~B}$ and Additional file 4: Figure S3). While the localizations of IFT81 in the two pseudorevertants (D12; $\mathrm{P}_{3243} \mathrm{~S}$ and $\mathrm{D} 42 \mathrm{~b} ; \mathrm{P}_{3243} \mathrm{R}$ ) at permissive temperature are identical to the pattern in wild-type cells, they show accumulation of IFT81 at the proximal ends of flagella after 6 hours and 4 hours at the restrictive temperature (Figure $7 \mathrm{~B}$ and Additional file 4: Figure S3), respectively. This suggests that the serine or arginine at the conserved leucine position does not completely restore function.

\section{Discussion}

Conditional mutants have been extremely useful in the study of essential genes in many cellular processes from ribosome assembly to cell division to secretion to synaptic 


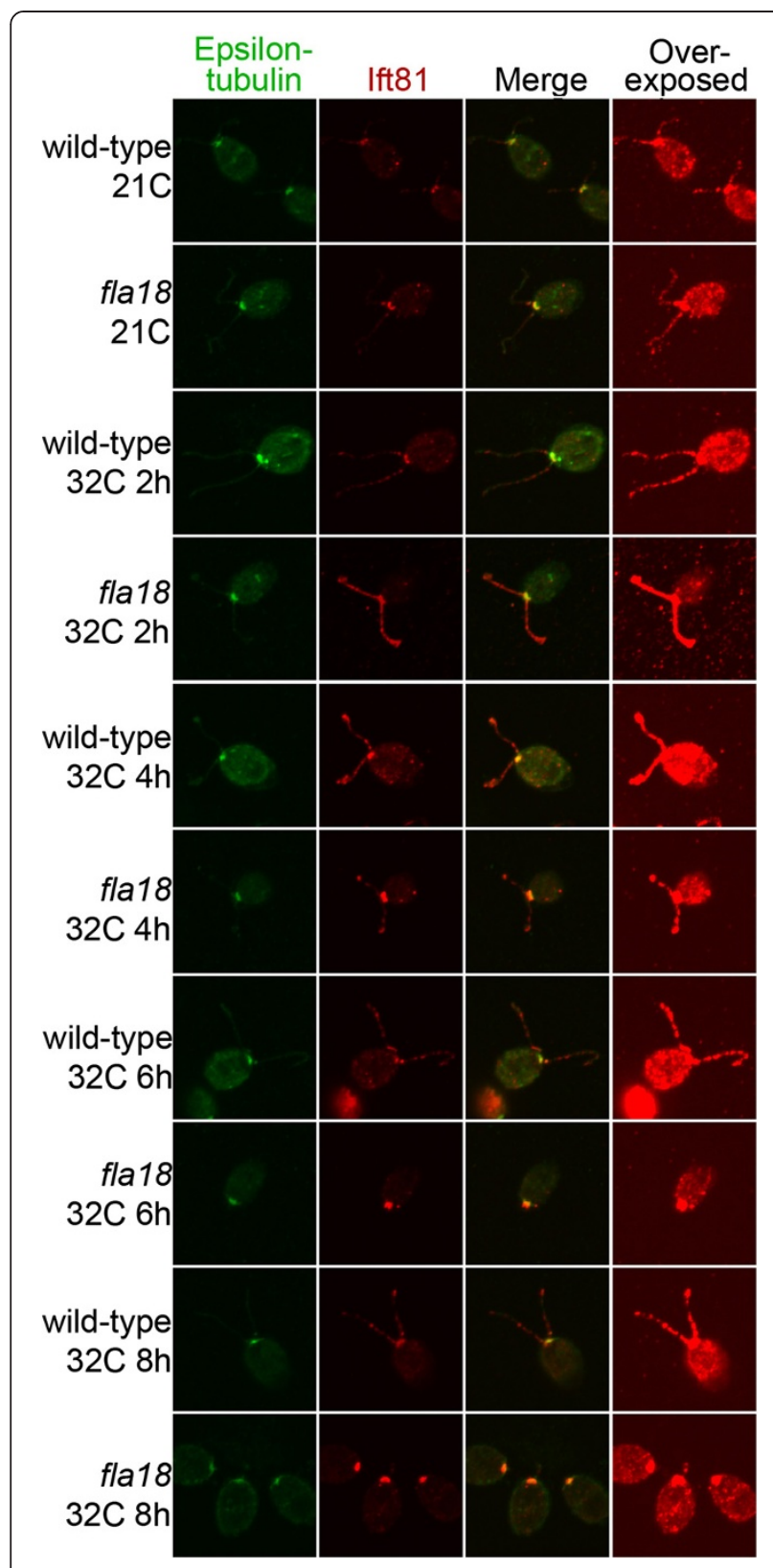

Figure 6 Localization of IFT81 in wild-type and fla 18 cells at $21^{\circ} \mathrm{C}$ and $32^{\circ} \mathrm{C}$. Staining of $\varepsilon$-tubulin (green), IFT81 (red), merged images, and overexposed IFT81 signals are shown. Cells were obtained from $21^{\circ} \mathrm{C}$ and various time points at $32^{\circ} \mathrm{C}$, as indicated.

vesicles. A collection of temperature-sensitive flagellar assembly mutants in Chlamydomonas has allowed the analysis of intraflagellar transport; they have documented that anterograde movement requires kinesin and IFT complex $\mathrm{B}$, and that retrograde movement requires cytoplasmic dynein and IFT complex A. In addition, remodeling of IFT trains at the tip requires IFT172, a protein in complex B, and a temperature-sensitive mutation in this protein leads to a retrograde defect (Table 1). Of the 21 extant conditional mutants, previous work together with this work has identified the causative lesion in 12 of them. All of these genes encode either IFT components or motor proteins (Table 1). Six have mutations in one of the three kinesin motor genes and four other mutations are in the cytoplasmic dynein motor. This bias suggests that conditionality may be more easily achieved in the motor subunits than in the IFT components.

Whole genome sequencing in Chlamydomonas has been fruitful when the gene is mapped to a region or chromosome [30]. We have developed a collection of changes in other wild-type and mutant strains that can be used to eliminate non-causative candidates [53]. In addition, the transcriptional profiles during regeneration of flagella are useful for identifying candidate flagellar assembly genes [54]. For fla18, we narrowed the list of candidates from 892 to 85 (Table 2) by combining the data from whole genome sequencing and transcriptional profiles. If we had used this strategy for fla24, only three of the 62 genomewide candidates showed increased levels of transcript during regeneration. For fla9 (unpublished data at Cilia), this strategy would have narrowed the 78 genome-wide candidates to eight. The use of both data sets may help to obviate the need for genome-wide fine mapping of flagellar assembly mutants.

The mutation in fla18 affects the same amino acid that is mutated in the fla10-14 strain. In fla10-14, the glutamic acid is changed to lysine but in fla18 (now renamed fla1016) it becomes a glycine. The two alleles have different kinetics of flagellar loss [8]; the $\mathrm{E}_{24} \mathrm{~K}$ allele takes over 12 hours to see loss of $50 \%$ of the flagella compared to the $\mathrm{E}_{24} \mathrm{G}$ allele that takes only 6 hours to see complete loss (Figure 2A). This glutamic acid is conserved in all kinesin2 molecules across the ciliated phylogenetic tree $(n=75$, data not shown). As speculated previously [8], it seems likely that this amino acid may interact with the P-loop and be important for motor activity. Interestingly, the fla2 mutant shows a 'fragile' phenotype [24]. Upon shifting cells to the restrictive temperature, the flagella detach rather than shorten. We observe similar detachment with the fla18 allele. Since fla18 greatly reduced anterograde IFT velocity, it is interesting to speculate that either a component is transported that maintains the integrity of the flagellar axoneme or a signal to maintain the integrity fails. This phenotype is allele-specific, which supports the idea that different alleles may provide different information about the functions of anterograde IFT.

The fla1 mutation (now fla8-2) and the fla8-1 mutation are in the second motor subunit of kinesin-2 [8]; they were thought to affect different phases of IFT [11]. The fla10-1 and fla8-1 alleles show similar phenotypes with normal anterograde velocity but a reduced ratio of anterograde to retrograde particles, while fla8-2 and fla18 show similar phenotypes with reduced anterograde 


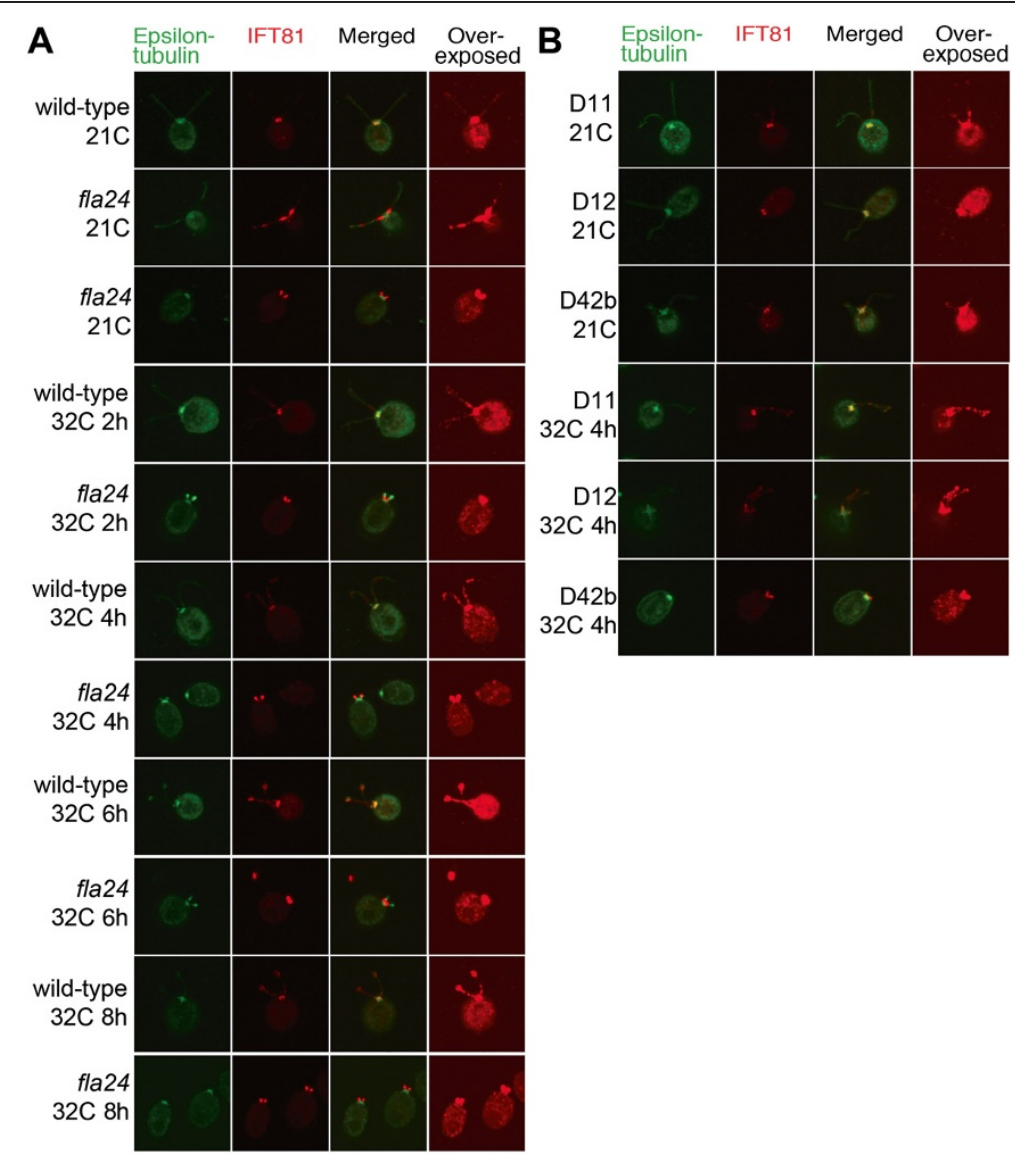

Figure 7 Localization of IFT81 in wild-type, fla24, and fla24 revertants at $21^{\circ} \mathrm{C}$ and $32^{\circ} \mathrm{C}$. Staining of $\varepsilon$-tubulin (green), IFT81 (red), merged images, and overexposed IFT81 signals are shown. Cells were obtained from $21^{\circ} \mathrm{C}$ and various time points at $32^{\circ} \mathrm{C}$, as indicated. (A) Wild-type and fla24 cells. (B) fla24 revertants.

velocity and a reduced ratio of anterograde to retrograde particles. Different mutations have different phenotypic effects on IFT.

fla24 is a mutation in the cytoplasmic dynein. The mutant fla24 allele has several helpful properties that will allow dissection of a successful IFT cycle. The IFT trains must be assembled at the basal bodies, turn around at the tip to change from anterograde to retrograde movement, and then be reloaded at the base for anterograde transport. In our study of fla15 (IFT144) and fla17 (IFT139) IFT complex A mutants, we observed that diploid cells heterozygous for fla 24 and either fla15 or fla17 were aflagellate at $32^{\circ} \mathrm{C}$ but flagellated at $21^{\circ} \mathrm{C}$ [31]. It is not unexpected that defects in complex A might show an enhancement of a cytoplasmic dynein mutant phenotype.

Since fla24 is compromised by reduced mutant Complex B proteins, we considered that the IFT dynein function may also be sensitized to dynein inhibitors since the retrograde velocity is reduced to $0.9 \mu \mathrm{m} / \mathrm{second}$ from 3.1 $\mu \mathrm{m} / \mathrm{second}$ for wild-type cells and the frequency of retrograde particles is reduced [11]. Ciliobrevin D is a small molecule that inhibits cytoplasmic dynein [55]. We asked if fla24 cells were more sensitive to ciliobrevin D than wild-type cells. Surprisingly, with the addition of $100 \mu \mathrm{M}$ ciliobrevin D, fla24 cells showed no effect on flagellar length after 30 minutes (data not shown), although this concentration has been shown to reduce the retrograde particle frequency after 5 minutes [56]. Further experiments to examine IFT particle rates with the mutant and inhibitor will shed more light on synthetic interactions.

Upon the shift of $f l a 24$ cells to $32^{\circ} \mathrm{C}$, the flagella are lost within 4 hours (Figure 2C); this is quite rapid compared to the other DHC1B alleles. The amount of DHC1b in flagella is greatly reduced as observed by immunofluorescence and immunoblot (Figure 4). The fla24 cells have three interesting phenotypes at $21^{\circ} \mathrm{C}$ that may suggest roles for the AAA5 domain of cytoplasmic dynein. First, the retrograde velocity and number of particles are reduced [11]. Second, the level of light intermediate chain (D1bLIC) is reduced as indicated by immunofluorescence and immunoblots (Figures $4 \mathrm{C}$ and 5). Third, the IFT81 protein distribution is dramatically altered; instead 
of localizing to the basal body and along the flagella, IFT81 has left the basal body region and is concentrated in the proximal approximate $1 \mu \mathrm{m}$ of the flagella (Figure 7A). Unlike the $d h c 1 b-3$ allele that shows a reversal in the direction of phototaxis [27], we never observed a change in the phototaxis phenotype of the fla24 mutant over a 6hour period (data not shown). Again, it is clear that different alleles have different phenotypic properties.

The cytoplasmic dynein molecule is composed of a central ATP-hydrolyzing ring that has six AAA modules arranged around the ring's central pore. The fla24 mutation falls into an alpha-helix in the AAA5 domain that is extended into the alpha helical strut/buttress $[57,58]$ (Figure 8 ). The strut/ buttress is postulated to have a high degree of plasticity that may be important for its function in communicating between the microtubule-binding domain (MTBD) of the stalk and the AAA ring. The distal region of the strut interacts with the middle of the stalk and a deletion of the distal end of the strut removes this interaction. Allosteric communication between AAA1 and MTBD is postulated to be relayed through the C-sequence, the strut, and the stalk [57].

Two in-frame deletions of 6 and 7 amino acids in the cytoplasmic dynein of Neurospora crassa affect the strut [60]. The $3739 \Delta 6$ amino acid deletion removes part of the first coil of the strut and is postulated to affect communication between the MTBD and the nucleotide status of the AAA1 domain. The dynein localizes distally in this mutant. The $3756 \Delta 7$ amino acid deletion is in the first coil of the strut as well but causes aggregation of the dynein. It is postulated that this mutation may lock the structure of the dynein. The cytoplasmic dynein mutants in Neurospora also demonstrate that different alleles have very different phenotypic effects [52].

The reduced retrograde velocity of IFT trains [31], the reduction in D1bLIC at the basal bodies, and the accumulation of IFT81 in the fla24 mutant suggest that the mutant has a defect in moving along the microtubules and in remodeling the IFT trains at the proximal end of the flagella via cargo binding. In our screen for suppressor and revertants of fla24, we have identified at least three genes that suppress the restrictive temperature flagellar assembly defect. These strains may provide information about interactions with the dynein heavy chain that will speak to how the strut and other structures communicate flagellar assembly defect (data not shown).

\section{Conclusions}

Whole genome sequencing provides a fast and inexpensive means to identify chemically induced mutations in Chlamydomonas [30,53]. Identification of the remaining seven temperature-sensitive mutations will be greatly helped by this technique. The identification of multiple mutant alleles in kinesin and in cytoplasmic dynein that have different phenotypes will greatly help studies of the function of these proteins. The fla18 allele is unique among the motor mutants in that it appears to deflagellate after the temperature shift instead of shortening. The fla24 allele results in an abnormal localization of IFT81 near the basal bodies at the permissive temperature, which may suggest a defect in recycling IFT trains.

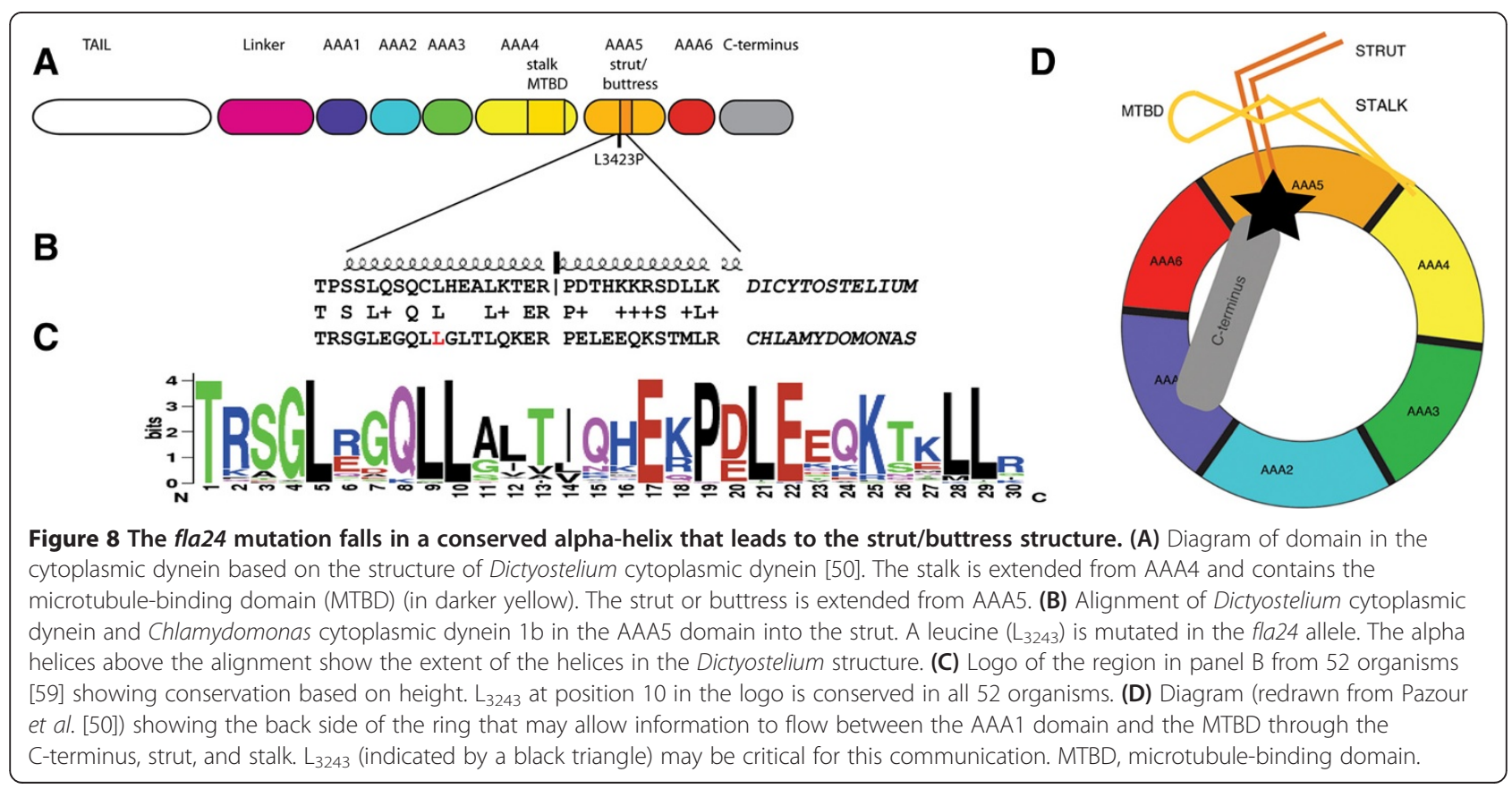




\section{Additional files}

Additional file 1: Table S1. Primers for reversion analysis of fla18 and fla 24.

Additional file 2: Figure S1. Localization of $\mathrm{DHC} 1 \mathrm{~b}$ in fla24 revertants at $32^{\circ} \mathrm{C}$. Staining of DHC1b (green), acetylated a-tubulin (red), merged images, and overexposed DHC1b signals are shown. Cells were obtained from various time points at $32^{\circ} \mathrm{C}$, as indicated.

Additional file 3: Figure S2. Localization of D1bLIC in fla24 revertants at $32^{\circ} \mathrm{C}$. Staining of D1bLIC (green), acetylated a-tubulin (red), merged images, and overexposed D1bLIC signals are shown. Cells were obtained from various time points at $32^{\circ} \mathrm{C}$, as indicated.

Additional file 4: Figure S3. Localization of IFT81 in fla24 revertants at $32^{\circ} \mathrm{C}$. Staining of $\varepsilon$-tubulin (green), IFT81 (red), merged images, and overexposed IFT81 signals are shown. Cells were obtained from various time points at $32^{\circ} \mathrm{C}$, as indicated.

\section{Abbreviations}

dCAPS: Degenerate cleaved amplified polymorphic sequence; DIC: Differential interference contrast; DTT: Dithiothreitol; HEPES: 4-(2-hydroxyethyl)-1piperazineethanesulfonic acid; HRP: Horseradish peroxidase; IFT: Intraflagellar transport; iTRAQ: Isobaric tags for relative and absolute quantitation; KAP: Kinesin-associated protein; mu: Map unit; MTBD: Microtubule-binding domain; NIH: National institutes of health; PBST: Phosphate-buffered saline tween; PCR: Polymerase chain reaction; PVDF: Polyvinylidene fluoride; RNAi: RNA interference; SNP: Single nucleotide polymorphism; UV: Ultraviolet.

\section{Competing interests}

The authors declare that they have no competing interests.

\section{Authors' contributions}

$\mathrm{HL}$ performed the analysis of the whole sequence, analysis of dynein subunit localization, and immunoblots. NPN measured flagellar length and number. AJA prepared and examined the samples for immunofluorescence, and examined the effect of ciliobrevin D. SH mapped meiotic progeny from crosses of fla $24 \times$ FLA24. SKD conceived of the study, performed the reversion analysis and $P C R$, and wrote the manuscript. All authors read and approved the final manuscript.

\section{Acknowledgements}

This work was supported by funds from the NIH (GM32834 to SKD). AJA is a Ruth L Kirschstein National Research Service Award fellow (GM093598). Silas Hsu was a Summer Scholar supported by funds from Washington University College of Arts and Science, St Louis, MO, USA, and from the Howard Hughes Medical Institute, Chevy Chase, MD, USA. We thank the Genome Technology Access Center (GTAC) in the Department of Genetics at Washington University School of Medicine, University City, MO, USA, for help with genomic analysis. GTAC is partially supported by National Cancer Institute Cancer Center Support grant \#P30 CA91842 to the Siteman Cancer Center, and by the Institute for Clinical and Translational Sciences (ICTS)/ Clinical and Translational Science Award (CTSA) grant UL1RR024992 from the National Center for Research Resources (NCRR), a component of the NIH and $\mathrm{NIH}$ Roadmap for Medical Research. GTAC sequencing is partially subsidized by the Children's Discovery Institute at Washington University School of Medicine. We thank Zhengyan Zhang for help with mapping of fla18. We thank Drs Doug Cole, Carlo lomini, Dennis Diener, and George Witman for antibodies.

Received: 4 April 2013 Accepted: 2 October 2013 Published: 30 Oct 2013

\section{References}

1. Kozminski KG, Johnson KA, Forscher P, Rosenbaum JL (1993) A motility in the eukaryotic flagellum unrelated to flagellar beating. Proc Natl Acad Sci U S A 90:5519-5523

2. Cole DG, Chinn SW, Wedaman KP, Hall K, Vuong T, Scholey JM (1993) Novel heterotrimeric kinesin-related protein purified from sea urchin eggs. Nature 366:268-270

3. Walther Z, Vashishtha M, Hall JL (1994) The Chlamydomonas FLA10 gene encodes a novel kinesin-homologous protein. J Cell Biol 126:175-188
4. Kozminski KG, Beech PL, Rosenbaum JL (1995) The Chlamydomonas kinesinlike protein FLA10 is involved in motility associated with the flagellar membrane. J Cell Biol 131:1517-1527

5. Cole DG, Diener DR, Himelblau AL, Beech PL, Fuster JC, Rosenbaum JL (1998) Chlamydomonas kinesin-II-dependent intraflagellar transport (IFT): IFT particles contain proteins required for ciliary assembly in Caenorhabditis elegans sensory neurons. J Cell Biol 141:993-1008

6. Piperno G, Mead K (1997) Transport of a novel complex in the cytoplasmic matrix of Chlamydomonas flagella. Proc Natl Acad Sci U S A 94:4457-4462

7. Mueller J, Perrone CA, Bower R, Cole DG, Porter ME (2005) The FLA3 KAP subunit is required for localization of kinesin-2 to the site of flagellar assembly and processive anterograde intraflagellar transport. Mol Biol Cell 16:1341-1354

8. Miller MS, Esparza JM, Lippa AM, Lux FG 3rd, Cole DG, Dutcher SK (2005) Mutant kinesin-2 motor subunits increase chromosome loss. Mol Biol Cell 16:3810-3820

9. Porter ME, Bower R, Knott JA, Byrd P, Dentler W (1999) Cytoplasmic dynein heavy chain $1 \mathrm{~b}$ is required for flagellar assembly in Chlamydomonas. Mol Biol Cell 10:693-712

10. Pazour GJ, Dickert BL, Witman GB (1999) The DHC1b (DHC2) isoform of cytoplasmic dynein is required for flagellar assembly. J Cell Biol 144:473-481

11. Iomini C, Babaev-Khaimov V, Sassaroli M, Piperno G (2001) Protein particles in Chlamydomonas flagella undergo a transport cycle consisting of four phases. J Cell Biol 153:13-24

12. Pigino G, Geimer S, Lanzavecchia S, Paccagnini E, Cantele F, Diener DR, Rosenbaum JL, Lupetti P (2009) Electron-tomographic analysis of intraflagellar transport particle trains in situ. J Cell Biol 187:135-148

13. Wei Q, Zhang Y, Li Y, Zhang Q, Ling K, Hu J (2012) The BBSome controls IFT assembly and turnaround in cilia. Nat Cell Biol 14:950-957

14. Nachury MV, Loktev AV, Zhang Q, Westlake CJ, Peranen J, Merdes A, Slusarski DC, Scheller RH, Bazan JF, Sheffield VC, Jackson PK (2007) A core complex of BBS proteins cooperates with the GTPase Rab8 to promote ciliary membrane biogenesis. Cell 129:1201-1213

15. Berbari NF, Johnson AD, Lewis JS, Askwith CC, Mykytyn K (2008) Identification of ciliary localization sequences within the third intracellular loop of G protein-coupled receptors. Mol Biol Cell 19:1540-1547

16. Berbari NF, Lewis JS, Bishop GA, Askwith CC, Mykytyn K (2008) Bardet-Biedl syndrome proteins are required for the localization of $\mathrm{G}$ protein-coupled receptors to primary cilia. Proc Natl Acad Sci U S A 105:4242-4246

17. Lechtreck KF, Brown JM, Sampaio JL, Craft JM, Shevchenko A, Evans JE, Witman GB (2013) Cycling of the signaling protein phospholipase D through cilia requires the BBSome only for the export phase. J Cell Biol 201:249-261

18. Ahmed NT, Gao C, Lucker BF, Cole DG, Mitchell DR (2008) ODA16 aids axonemal outer row dynein assembly through an interaction with the intraflagellar transport machinery. J Cell Biol 183:313-322

19. Eggenschwiler JT, Anderson KV (2007) Cilia and developmental signaling Annu Rev Cell Dev Bio 23:345-373

20. Schmidts M, Arts HH, Bongers EM, Yap Z, Oud MM, Antony D, Duijkers L Emes RD, Stalker J, Yntema JB, Plagnol V, Hoischen A, Gilissen C, Forsythe E, Lausch E, Veltman JA, Roeleveld N, Superti-Furga A, Kutkowska-Kazmierczak A, Kamsteeg EJ, Elçioğlu N, van Maarle MC, Graul-Neumann LM, Devriendt K, Smithson SF, Wellesley D, Verbeek NE, Hennekam RC, Kayserili H, Scambler PJ (2013) Exome sequencing identifies DYNC2H1 mutations as a common cause of asphyxiating thoracic dystrophy (Jeune syndrome) without major polydactyly, renal or retinal involvement. J Med Genet 50:309-323

21. Beales PL, Bland E, Tobin JL, Bacchelli C, Tuysuz B, Hill J, Rix S, Pearson CG, Kai M, Hartley J, Johnson C, Irving M, Elcioglu N, Winey M, Tada M, Scambler PJ (2007) IFT80, which encodes a conserved intraflagellar transport protein, is mutated in Jeune asphyxiating thoracic dystrophy. Nature Genet 39:727-729

22. Bredrup C, Saunier S, Oud MM, Fiskerstrand T, Hoischen A, Brackman D, Leh SM, Midtbo M, Filhol E, Bole-Feysot C, Nitschké P, Gilissen C, Haugen OH, Sanders JS, Stolte-Dijkstra I, Mans DA, Steenbergen EJ, Hamel BC, Matignon M, Pfundt R, Jeanpierre C, Boman H, Rødahl E, Veltman JA, Knappskog PM, Knoers NV, Roepman R, Arts HH (2011) Ciliopathies with skeletal anomalies and renal insufficiency due to mutations in the IFT-A gene WDR19. Am J Hum Genet 89:634-643

23. Perrault I, Saunier S, Hanein S, Filhol E, Bizet AA, Collins F, Salih MA, Gerber S, Delphin N, Bigot K, Orssaud C, Silva E, Baudouin V, Oud MM, Shannon N, Le Merrer M, Roche O, Pietrement C, Goumid J, Baumann C, Bole-Feysot C, Nitschke P, Zahrate M, Beales P, Arts HH, Munnich A, Kaplan J, Antignac C, 
Cormier-Daire V, Rozet JM (2012) Mainzer-Saldino syndrome is a ciliopathy caused by IFT140 mutations. Am J Hum Genet 90:864-870

24. Huang B, Rifkin MR, Luck DJ (1977) Temperature-sensitive mutations affecting flagellar assembly and function in Chlamydomonas reinhardtii. J Cell Biol 72:67-85

25. Adams GM, Huang B, Luck DJ (1982) Temperature-sensitive, assembly-defective flagella mutants of Chlamydomonas reinhardtii. Genetics 100:579-586

26. Pedersen LB, Miller MS, Geimer S, Leitch JM, Rosenbaum JL, Cole DG (2005) Chlamydomonas IFT172 is encoded by FLA11, interacts with CrEB1, and regulates IFT at the flagellar tip. Curr Biol 15:262-266

27. Engel BD, Ishikawa H, Wemmer KA, Geimer S, Wakabayashi K, Hirono M, Craige B, Pazour GJ, Witman GB, Kamiya R, Marshall WF (2012) The role of retrograde intraflagellar transport in flagellar assembly, maintenance, and function. J Cell Biol 199:151-167

28. Parker JD, Quarmby LM (2003) Chlamydomonas fla mutants reveal a link between deflagellation and intraflagellar transport. BMC Cell Biol 4:11

29. Ramanis Z, Luck DJ (1986) Loci affecting flagellar assembly and function map to an unusual linkage group in Chlamydomonas reinhardtii. Proc Natl Acad Sci U S A 83:423-426

30. Dutcher SK, Li L, Lin H, Meyer L, Giddings TH Jr, Kwan AL, Lewis BL (2012) Whole-genome sequencing to identify mutants and polymorphisms in Chlamydomonas reinhardtii. G3 2:15-22

31. Iomini C, Li L, Esparza JM, Dutcher SK (2009) Retrograde intraflagellar transport mutants identify complex a proteins with multiple genetic interactions in Chlamydomonas reinhardtii. Genetics 183:885-896

32. Witman GB (2012) Dynein and Intraflagellar Transport. In: King SM (ed) Dyneins: Structure, Biology and Disease. Elsevier, London

33. Matsuura K, Lefebvre PA, Kamiya R, Hirono M (2002) Kinesin-II is not essential for mitosis and cell growth in Chlamydomonas. Cell Motil Cytoskeleton 52:195-201

34. Pazour GJ, Wilkerson CG, Witman GB (1998) A dynein light chain is essential for the retrograde particle movement of intraflagellar transport (IFT). J Cell Biol 141:979-992

35. Hou Y, Qin H, Follit JA, Pazour GJ, Rosenbaum JL, Witman GB (2007) Functional analysis of an individual IFT protein: IFT46 is required for transport of outer dynein arms into flagella. J Cell Biol 176:653-665

36. Lucker BF, Miller MS, Dziedzic SA, Blackmarr PT, Cole DG (2010) Direct interactions of intraflagellar transport complex B proteins IFT88, IFT52, and IFT46. J Biol Chem 285:21508-21518

37. Brazelton WJ, Amundsen CD, Silflow CD, Lefebvre PA (2001) The bld1 mutation identifies the Chlamydomonas osm- 6 homolog as a gene required for flagellar assembly. Curr Biol 11:1591-1594

38. Deane JA, Cole DG, Seeley ES, Diener DR, Rosenbaum JL (2001) Localization of intraflagellar transport protein IFT52 identifies basal body transitional fibers as the docking site for IFT particles. Curr Biol 11:1586-1590

39. Lucker BF, Behal RH, Qin H, Siron LC, Taggart WD, Rosenbaum JL, Cole DG (2005) Characterization of the intraflagellar transport complex B core: direct interaction of the IFT81 and IFT74/72 subunits. J Biol Chem 280:27688-27696

40. Pazour GJ, Baker SA, Deane JA, Cole DG, Dickert BL, Rosenbaum JL, Witman GB, Besharse JC (2002) The intraflagellar transport protein, IFT88, is essential for vertebrate photoreceptor assembly and maintenance. J Cell Biol 157:103-113

41. Behal RH, Miller MS, Qin H, Lucker BF, Jones A, Cole DG (2012) Subunit interactions and organization of the Chlamydomonas reinhardtii intraflagellar transport complex A proteins. J Biol Chem 287:11689-11703

42. Hou Y, Pazour GJ, Witman GB (2004) A dynein light intermediate chain, D1bLIC, is required for retrograde intraflagellar transport. Mol Biol Cell 15:4382-4394

43. Qin H, Wang Z, Diener D, Rosenbaum J (2007) Intraflagellar transport protein 27 is a small G protein involved in cell-cycle control. Curr Biol 17:193-202

44. Fan ZC, Behal RH, Geimer S, Wang Z, Williamson SM, Zhang H, Cole DG, Qin H (2010) Chlamydomonas IFT70/CrDYF-1 is a core component of IFT particle complex B and is required for flagellar assembly. Mol Biol Cell 21:2696-2706

45. Mitchell DR, Kang Y (1991) Identification of oda6 as a Chlamydomonas dynein mutant by rescue with the wild-type gene. J Cell Biol 113:835-842

46. LeDizet M, Piperno G (1995) Ida, 4-1, ida4-2, and ida4-3 are intron splicing mutations affecting the locus encoding p28, a light chain of Chlamydomonas axonemal inner dynein arms. Mol Biol Cell 6:713-723
47. Bhogaraju S, Cajanek L, Fort C, Blisnick T, Weber K, Taschner M, Mizuno N, Lamla S, Bastin P, Nigg EA, Lorentzen E (2013) Molecular basis of tubulin transport within the cilium by IFT74 and IFT81. Science 341:1009-1012

48. Neff MM, Turk E, Kalishman M (2002) Web-based primer design for single nucleotide polymorphism analysis. Trends Genet 18:613-615

49. Piperno G, Huang B, Luck DJ (1977) Two-dimensional analysis of flagellar proteins from wild-type and paralyzed mutants of Chlamydomonas reinhardtii. Proc Natl Acad Sci U S A 74:1600-1604

50. Rupp G, OToole E, Gardner LC, Mitchell BF, Porter ME (1996) The sup-pf-2 mutations of Chlamydomonas alter the activity of the outer dynein arms by modification of the gamma-dynein heavy chain. J Cell Biol 135:1853-1865

51. Dutcher SK, Morrissette NS, Preble AM, Rackley C, Stanga I (2002) Epsilontubulin is an essential component of the centriole. Mol Biol Cell 13:3859-3869

52. Dutcher SK, Huang B, Luck DJ (1984) Genetic dissection of the central pair microtubules of the flagella of Chlamydomonas reinhardtii. J Cell Biol 98:229-236

53. Lin H, Miller M, Granas D, Dutcher S (2013) Whole genome sequencing reveals distinct functions of a protein phosphatase 2A in Chlamydomonas mating. PLoS Genet 9:e1003841

54. Albee AJ, Kwan AL, Lin H, Granas D, Stormo GD, Dutcher SK (2013) Identification of cilia genes that affect cell-cycle progression using wholegenome transcriptome analysis in Chlamydomonas reinhardtti. G3 3:979-991

55. Firestone AJ, Weinger JS, Maldonado M, Barlan K, Langston LD, O'Donnell M, Gelfand VI, Kapoor TM, Chen JK (2012) Small-molecule inhibitors of the AAA+ ATPase motor cytoplasmic dynein. Nature 484:125-129

56. Shih SM, Engel BD, Kocabas F, Bilyard T, Gennerich A, Marshall WF, Yildiz A (2013) Intraflagellar transport drives flagellar surface motility. Elife 2:e00744

57. Kon T, Oyama T, Shimo-Kon R, Imamula K, Shima T, Sutoh K, Kurisu G (2012) The 2.8 A crystal structure of the dynein motor domain. Nature 484:345-350

58. Schmidt H, Gleave ES, Carter AP (2012) Insights into dynein motor domain function from a 3.3-A crystal structure. Nat Struct Mol Biol 19:492-497

59. Crooks GE, Hon G, Chandonia JM, Brenner SE (2004) WebLogo: a sequence logo generator. Genome Res 14:1188-1190

60. Sivagurunathan S, Schnittker RR, Razafsky DS, Nandini S, Plamann MD, King SJ (2012) Analyses of dynein heavy chain mutations reveal complex interactions between dynein motor domains and cellular dynein functions. Genetics 191:1157-1179

10.1186/2046-2530-2-14

Cite this article as: Lin et al:: New mutations in flagellar motors identified by whole genome sequencing in Chlamydomonas. Cilia 2013, 2:14

\section{Submit your next manuscript to BioMed Central and take full advantage of:}

- Convenient online submission

- Thorough peer review

- No space constraints or color figure charges

- Immediate publication on acceptance

- Inclusion in PubMed, CAS, Scopus and Google Scholar

- Research which is freely available for redistribution 